\title{
Phylogenetic Analysis of Acinetobacter Strains Based on the Nucleotide Sequences of gyrB Genes and on the Amino Acid Sequences of Their Products
}

\author{
SATOSHI YAMAMOTO* AND SHIGEAKI HARAYAMA \\ Marine Biotechnology Institute, Kamaishi Laboratories, Kamaishi City, Iwate 026, Japan
}

\begin{abstract}
Partial nucleotide sequences of the gyrB genes (DNA gyrase B subunit genes) of 15 Acinetobacter strains, including the type and reference strains of genomic species 1 to 12 (A. calcoaceticus [genomic species 1], $A$. baumannii [genomic species 2], Acinetobacter genomic species 3, A. haemolyticus [genomic species 4], A. junii [genomic species 5], Acinetobacter genomic species 6, $A$. johnsonii [genomic species 7], $A$. Iwoffi [genomic species 8], Acinetobacter genomic species 9, Acinetobacter genomic species 10, Acinetobacter genomic species 11, and $A$. radioresistens [genomic species 12]), were determined by sequencing the PCR-amplified fragments of gyrB. The gyrB sequence homology among these Acinetobacter strains ranged from 69.6 to $99.7 \%$. A phylogenetic analysis, using the gyr $B$ sequences, indicates that genomic species 1,2 , and 3 formed one cluster $(87.3$ to $90.3 \%$ identity), while genomic species 8 and 9 formed another cluster (99.7\% identity). These results are consistent with those of DNA-DNA hybridization and of biochemical systematics. On the other hand, the topology of the published phylogenetic tree based on the 16S rRNA sequences of the Acinetobacter strains was quite different from that of the gyrB-based tree. The numbers of substitution in the 16S rRNA gene sequences were not high enough to construct a reliable phylogenetic tree. The gyrB-based analysis indicates that the genus Acinetobacter is highly diverse and that a reclassification of this genus would be required.
\end{abstract}

The nucleotide sequences of small-subunit rRNA (16S rRNA) have been used most frequently to deduce the phylogenetic relationships between bacteria $(15,24,32,48)$. However, the results of $16 \mathrm{~S}$ rRNA sequence analysis have often disagreed with the results using DNA reassociation, which is considered to be an absolute measure of relatedness (16, 34, 44). The major reason for this discrepancy may be the low rate of base substitution in 16S rRNA genes: the numbers of substituted bases between rRNA genes from closely related bacteria are small, and a comparison of almost identical sequences is accompanied by a large statistical error. The use of proteincoding genes that are known to evolve much faster than rRNAs seems to be more appropriate for the phylogenetic analysis of closely related bacteria. We have developed universal PCR primers with which the amplification and sequencing of gyr $B$ genes (the DNA gyrase B subunit genes) from a variety of bacteria were possible (49). We were thus interested in using these gyrB sequences in molecular systematics.

Acinetobacter strains are ubiquitous in the natural environment and are implicated in the biodegradation of a variety of hydrocarbons and in some human diseases $(1,3,35,40,42,47)$. The establishment of effective typing systems for this genus is especially important because of outbreaks of Acinetobacter infections in hospitals $(8,11)$. Several methods, including ribotyping, cellular fatty acid compositional analysis, cell envelope protein profiling, plasmid DNA fingerprinting, and phage typing, have been used to classify this genus $(6,8,17,21,22,26$, $28,33,41,46)$. The definition of the genus by DNA-DNA hybridization comprises at least 19 genomic species (DNA groups) $(5,7,18,45,46)$. In this study, we carried out a phylogenetic analysis of 15 Acinetobacter strains by using their

* Corresponding author. Mailing address: Marine Biotechnology Institute, Kamaishi Laboratories, 3-75-1 Heita, Kamaishi City, Iwate 026, Japan. Phone: 81-193-26-6544. Fax: 81-193-26-6592 or 81-193-26-6584. Electronic mail address: HGD02251@niftyserve.or.jp.
gyrB sequences, and we compare the results with those from conventional taxonomic studies.

\section{MATERIALS AND METHODS}

Bacterial strains. The following type strains and reference strains of genomic species 1 to $12(5,31,45)$ were presented by P. J. M. Bouvet of Institut Pasteur in Paris, France: Acinetobacter calcoaceticus CIP $81.08^{\mathrm{T}}$ (= ATCC $23055^{\mathrm{T}}$; genomic species 1), A. baumannii CIP $70.34^{\mathrm{T}}$ (= ATCC $19606^{\mathrm{T}}$; genomic species 2), Acinetobacter sp. strain CIP 70.29 (= ATCC 19004; genomic species 3), A. haemolyticus CIP $64.3^{\mathrm{T}}$ (= ATCC $17906^{\mathrm{T}}$; genomic species 4$), A$. junii CIP $64.5^{\mathrm{T}}$ $\left(=\right.$ ATCC $17908^{\mathrm{T}}$; genomic species 5$)$, Acinetobacter sp. strain CIP A165 (= ATCC 17979; genomic species 6), A. johnsonii CIP $64.6^{\mathrm{T}}$ (= ATCC $17909^{\mathrm{T}}$; genomic species 7), A. lwoffi CIP $64.10^{\mathrm{T}}$ (= NCTC $5866^{\mathrm{T}}$; genomic species 8 ), Acinetobacter sp. strain CIP 70.31 (= ATCC 9957; genomic species 9), Acinetobacter sp. strain CIP 70.12 (= ATCC 17924; genomic species 10), Acinetobacter sp. strain CIP 63.46 (= ATCC 11171; genomic species 11), and A. radioresistens SEIP 12.81 (genomic species 12). Two strains, A. calcoaceticus ATCC $31012(=$ RAG-1) $(19,36)$ and $A$. calcoaceticus ATCC 33308 (= BD 413 ErpE27) $(27,39)$, were purchased from American Type Culture Collection. Acinetobacter sp. strain T4 has been isolated from the Pacific Ocean as a bacterium degrading $n$-tetradecan. Chemical taxonomy has classified this strain as a member of the genus Acinetobacter (unpublished data).

Preparation of chromosomal DNA. Bacteria were grown aerobically in nutrient broth at $30^{\circ} \mathrm{C}$, cells from overnight cultures being washed and resuspended in a TE buffer ( $10 \mathrm{mM}$ Tris-HCl and $1 \mathrm{mM}$ EDTA at $\mathrm{pH} 7.5)$. Chromosomal DNA was prepared by the method described by Johnson (25).

PCR amplification and direct sequencing of $g y r B$. The gyr $B$ fragments of the Acinetobacter strains were amplified and sequenced as described previously (49). PCR amplification was performed with a DNA Thermal Cycler 480 (PerkinElmer Co. Norwalk, Conn.) with a PCR buffer (Perkin-Elmer Co.) containing each of the deoxynucleoside triphosphates at a concentration of $200 \mu \mathrm{M}$, each of the primers at a concentration of $1 \mu \mathrm{M}, 1 \mu \mathrm{g}$ of target DNA, and $2.5 \mathrm{U}$ of Taq DNA polymerase in a total volume of $100 \mu \mathrm{l}$. A total of 30 amplification cycles was performed with template DNA denaturation at $94^{\circ} \mathrm{C}$ for $1 \mathrm{~min}$, primer annealing at $60^{\circ} \mathrm{C}$ for $1 \mathrm{~min}$, and primer extension at $72^{\circ} \mathrm{C}$ for $2 \mathrm{~min}$. The amplified products were purified by preparative gel electrophoresis on $1 \%$ lowmelting-temperature agarose (NuSieve GTG; FMC Bioproducts, Rockland, Maine) according to the method described by Sambrook et al. (38) before each $\mathrm{N}$-terminal and $\mathrm{C}$-terminal 300 -bp stretch of the amplified fragments was sequenced. The sequencing reaction was conducted by using a Taq DyeDeoxy Terminator cycle sequencing kit according to the manufacturer's instructions, and the products were analyzed with a 373A DNA sequencer (Applied Biosystems, Foster City, Calif.).

Phylogenetic data analysis. The nucleotide sequences of $g y r B$ or their translated amino acid $(\mathrm{GyrB})$ sequences were aligned by using the CLUSTAL V 


\section{A: N-terminal region}

\begin{tabular}{|c|c|}
\hline genomic sp. 1 & RVGVSVVNALSSKLHLMISRAGQVHEQEYQHGDPQY \\
\hline genomic sp. 2 & $1, \ldots \ldots$ G....... \\
\hline enomic sp. 3 & $1: \ldots \ldots \ldots \ldots, \ldots \ldots \ldots \ldots \ldots$ I.N. . . \\
\hline lomic sp. & 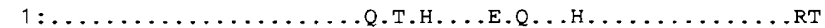 \\
\hline enomic sp. & 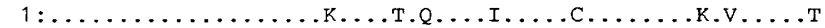 \\
\hline enomic sp. & 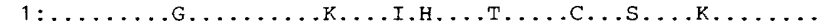 \\
\hline genomic sp. 7 & 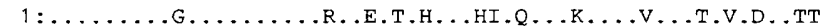 \\
\hline genomic sp. 8 & 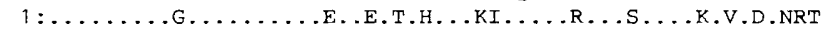 \\
\hline genomic sp. 9 & 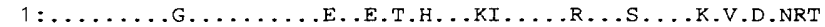 \\
\hline genomic sp. 10 & 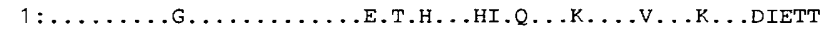 \\
\hline genomic sp. 11 & 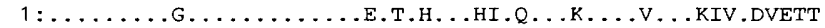 \\
\hline genomic sp. 12 & 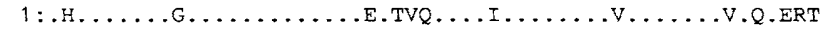 \\
\hline ATCC 31012 & $1: \ldots \ldots$. $\ldots$. \\
\hline ATCC 33308 & 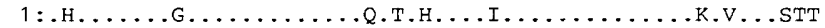 \\
\hline & $1: \ldots \ldots$ L. \\
\hline genomic sp. $\hat{\imath}$ & 61 :RFWPSELTFTQT IFNVEILARRLRELSFLNAGVRIVLRDER INLGHVFDYEGGLSE \\
\hline genomic sp. & $61: \ldots$ АЕ. \\
\hline genomic sp. & 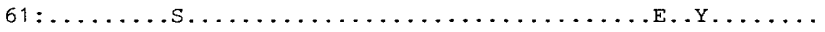 \\
\hline genomic sp. & 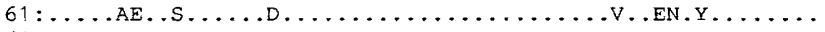 \\
\hline genomic sp. & 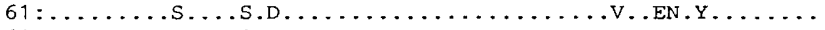 \\
\hline genomic sp. & 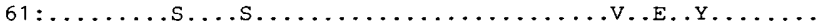 \\
\hline genomic sp. & $61: \ldots$. AE. .S. . . . D.... \\
\hline genomic sp. 8 & $61: \ldots$ AE..S .... . . . \\
\hline genomic sp. 9 & $61: \ldots$ AE..S, . . D. . . . . L . . \\
\hline genomic sp. 10 & $61 ; \ldots \ldots$ AE..S, . . . . . . . . . . . . \\
\hline genomic sp. 11 & 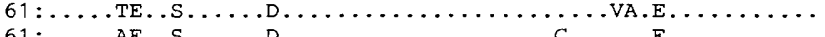 \\
\hline ATCC 31012 & 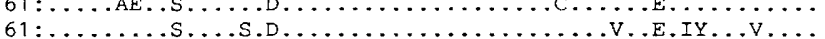 \\
\hline ATCC 33308 & 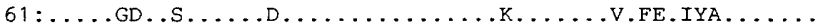 \\
\hline T4 & $61: \ldots \ldots$ W.S. KS.D. \\
\hline
\end{tabular}

\section{B: C-terminal region}

genomic sp. 1
genomic sp. 2
genomic sp. 3
genomic sp. 4
genomic sp. 5
genomic sp. 6
genomic sp. 7
genomic sp. 8
genomic sp. 9
genomic sp. 10
genomic sp. 11
genomic sp. 12
ATCC 31012
ATCC 33308
T4

genomic sp. 1
genomic sp. 2
genomic sp. 3
genomic sp. 4
genomic sp. 5
genomic sp. 6
genomic sp. 7
genomic sp. 8
genomic sp. 9
genomic sp. 10
genomic sp. 11
genomic sp. 12
ATC 31012
ATCC 33308
T4

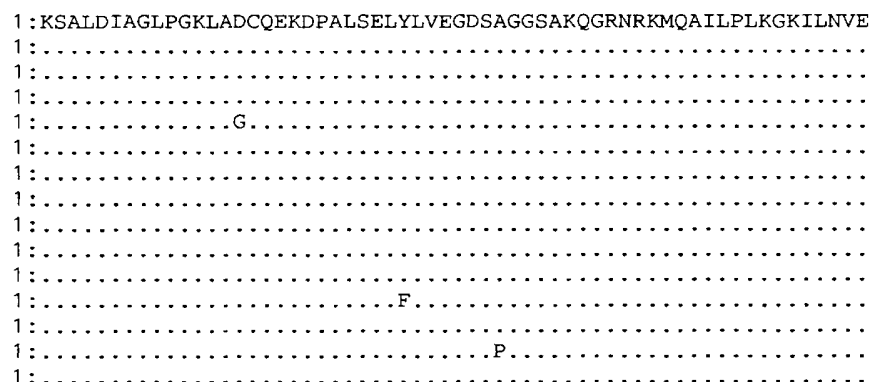

61 :RARFDKMISSQEVGTLITALGCGIGREEYNPDKLRYHKII

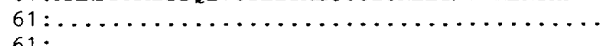

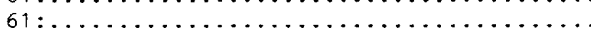

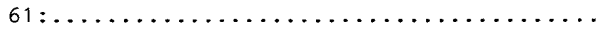

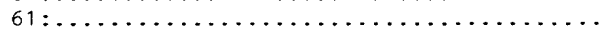

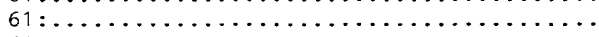

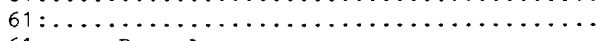

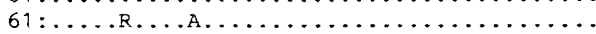

$61: \ldots \ldots R \ldots$. A . . . . . . . . . . . . .

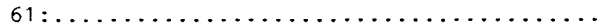

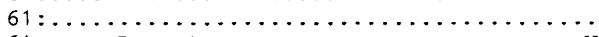

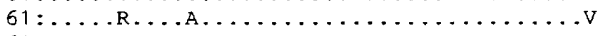

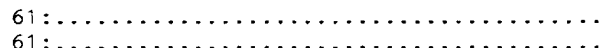

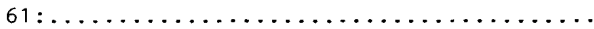

FIG. 1. Amino acid sequence alignment of the gyrB products of 15 Acinetobacter strains. Amino acids identical to those in the genomic species 1 ( $A$. calcoaceticus CIP $81.08^{\mathrm{T}}$ ) sequence are indicated with dots. (A) Sequence alignment for the N-terminal region of the amplified fragment corresponds to positions 107 to 223 of the E. coli K-12 sequence (accession number P06982). (B) Sequence alignment for the C-terminal region corresponds to positions 394 to 493 of the E. coli K-12 sequence. 
TABLE 1. Nucleotide sequence homology of gyrB between strains of the genus Acinetobacter

\begin{tabular}{|c|c|c|c|c|c|c|c|c|c|c|c|c|c|c|c|}
\hline \multirow{2}{*}{ Strain no. and name } & \multirow{2}{*}{$\begin{array}{c}\text { Genomic } \\
\text { species }\end{array}$} & \multicolumn{14}{|c|}{ Nucleotide sequence homology $(\%)$ with strain: } \\
\hline & & 1 & 2 & 3 & 4 & 5 & 6 & 7 & 8 & 9 & 10 & 11 & 12 & 13 & 14 \\
\hline 1 A. calcoaceticus CIP $81.08^{\mathrm{T}}$ & 1 & & & & & & & & & & & & & & \\
\hline 2 A. baumannii CIP $70.34^{\mathrm{T}}$ & 2 & 88.0 & & & & & & & & & & & & & \\
\hline 3 Acinetobacter sp. strain CIP 70.29 & 3 & 90.3 & 87.3 & & & & & & & & & & & & \\
\hline 4 A. haemolyticus CIP $64.3^{\mathrm{T}}$ & 4 & 81.7 & 81.0 & 83.4 & & & & & & & & & & & \\
\hline 5 A. junii CIP $64.5^{\mathrm{T}}$ & 5 & 82.0 & 81.7 & 81.7 & 82.8 & & & & & & & & & & \\
\hline 6 Acinetobacter sp. strain CIP A165 & 6 & 81.0 & 79.4 & 82.0 & 81.3 & 80.6 & & & & & & & & & \\
\hline 7 A. johnsonii CIP $64.6^{\mathrm{T}}$ & 7 & 76.7 & 77.6 & 77.7 & 81.1 & 79.3 & 77.0 & & & & & & & & \\
\hline 8 A. lwoffii CIP $64.10^{\mathrm{T}}$ & 8 & 77.0 & 77.9 & 77.1 & 78.2 & 80.2 & 77.7 & 80.5 & & & & & & & \\
\hline 9 Acinetobacter sp. strain CIP 70.31 & 9 & 77.0 & 77.6 & 76.8 & 77.9 & 80.2 & 77.7 & 80.2 & 99.7 & & & & & & \\
\hline 10 Acinetobacter sp. strain CIP 70.12 & 10 & 77.1 & 78.5 & 77.6 & 79.0 & 77.0 & 77.1 & 79.0 & 77.6 & 77.6 & & & & & \\
\hline 11 Acinetobacter sp. strain CIP 63.46 & 11 & 79.6 & 79.7 & 79.4 & 79.6 & 78.3 & 77.6 & 81.1 & 79.1 & 78.8 & 85.6 & & & & \\
\hline 12 Acinetobacter sp. strain SEIP 12.81 & 12 & 75.4 & 76.8 & 74.2 & 76.5 & 75.0 & 75.4 & 77.3 & 79.6 & 79.6 & 75.3 & 75.3 & & & \\
\hline 13 Acinetobacter sp. strain T4 & & 80.0 & 81.4 & 81.1 & 82.2 & 85.9 & 82.8 & 76.7 & 78.3 & 78.0 & 78.6 & 79.1 & 73.6 & & \\
\hline 14 ATCC 31012 & & 80.6 & 81.7 & 81.9 & 82.2 & 86.3 & 83.1 & 77.0 & 79.3 & 79.0 & 79.1 & 79.7 & 74.7 & 98.8 & \\
\hline 15 ATCC 33308 & & 70.2 & 73.6 & 70.8 & 71.7 & 73.0 & 69.6 & 73.0 & 73.9 & 73.6 & 70.5 & 72.4 & 75.4 & 70.2 & 71.1 \\
\hline
\end{tabular}

computer program (23). Evolutionary trees were constructed with the PHYLIP computer program package (13), using the neighbor-joining method (37).

Nucleotide sequence accession numbers. The nucleotide sequence data reported in this paper will appear in the DDBJ, EMBL, and GenBank nucleotide sequence databases with the following accession numbers (first and second numbers indicate the $5^{\prime}$ and $3^{\prime}$ regions of $\operatorname{gyr} B$, respectively): genomic species 1 , D73427 and D73412; genomic species 2, D73428 and D73413; genomic species 3, D73429 and D73414; genomic species 4, D73430 and D73415; genomic species 5, D73431 and D73416; genomic species 6, D73417 and D73432; genomic species 7, D73433 and D73418; genomic species 8, D73434 and D73419; genomic species 9 D73435 and D73420; genomic species 10, D73436 and D73421; genomic species 11, D73437 and D73422; genomic species 12, D73438 and D73423; ATCC 31012 , D73440 and D73425; ATCC 33308, D73441 and D73426; and T4, D73439 and D73424.

\section{RESULTS AND DISCUSSION}

Nucleotide sequences of gyrB. The partial nucleotide sequences of gyrB from 15 Acinetobacter strains were determined as described in Materials and Methods. The alignment of the GyrB amino acid sequences translated from the obtained gyrB nucleotide sequences is shown in Fig. 1. The percentage of nucleotide substitutions in the $g y r B$ genes varied from 0.3 to $30.4 \%$ (Table 1 ), while the percentage of substitutions in the amino acid sequences was between 0.5 and $13.3 \%$.

Phylogenetic structure based on gyrB. The phylogenetic tree based on the gyrB nucleotide sequences is shown in Fig. 2. $A$. calcoaceticus (genomic species 1), A. baumannii (genomic species 2), and an Acinetobacter sp. (genomic species 3) formed one cluster ( 87.3 to $90.3 \%$ identity), while $A$. lwoffii (genomic species 8) and an Acinetobacter sp. (genomic species 9) formed another cluster ( $99.7 \%$ identity). The topologies of the phylogenetic trees produced by the neighbor-joining method (37), maximum-parsimony method (14), maximum-likelihood method (12), and unweighted pair-group method (43) were almost identical (data not shown).

Strains ATCC 31012 and ATCC 33308 have been classified as members of $A$. calcoaceticus (genomic species 1) (19, 27, 36, 39 ), but they were localized in branches different from the branch of the $A$. calcoaceticus type strain. The crude oil-degrading strain ATCC 31012 (RAG-1) producing the biosurfactant emulsan (19) was closely related to the $n$-tetradecan-degrading Acinetobacter sp. strain T4 (98.8\% identity) and, to a lesser extent, to $A$. junii CIP $64.5^{\mathrm{T}}$ (genomic species $5 ; 86.3 \%$ identity). Strain ATCC 33308 has been used as the competent

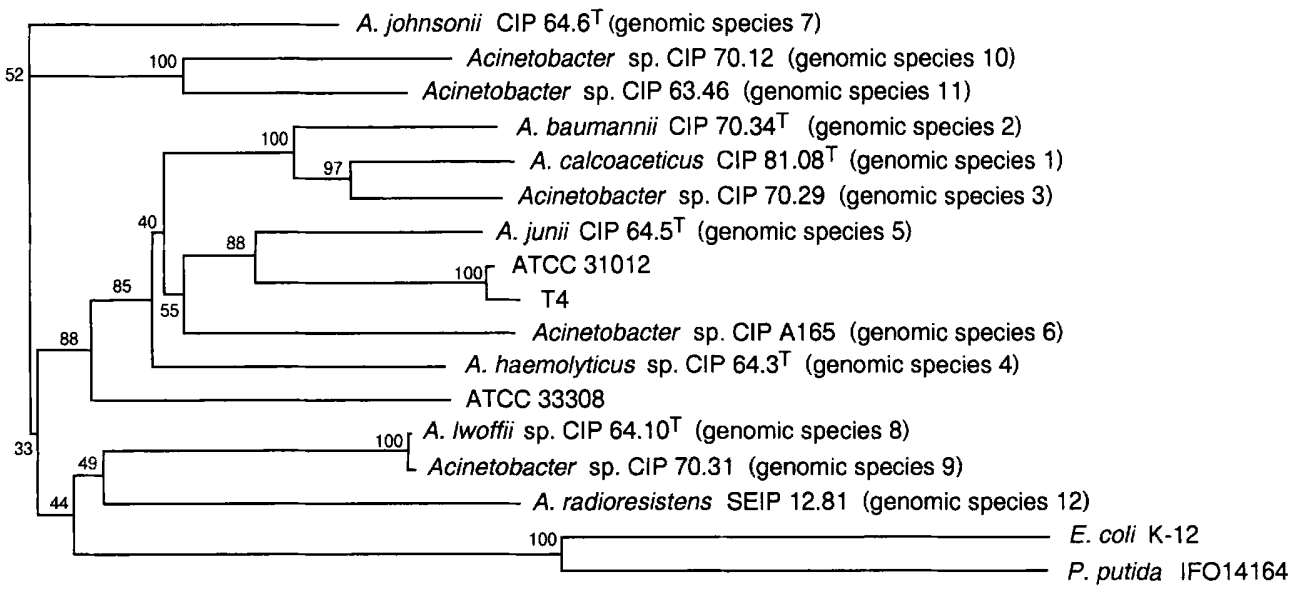

10

FIG. 2. Phylogenetic tree for the strains of Acinetobacter based on the gyrB nucleotide sequences by the neighbor-joining method. The numbers shown next to the nodes indicate percent bootstrap values of the 500 replicates. Genetic distances were computed by using Kimura's two-parameter model (29). 


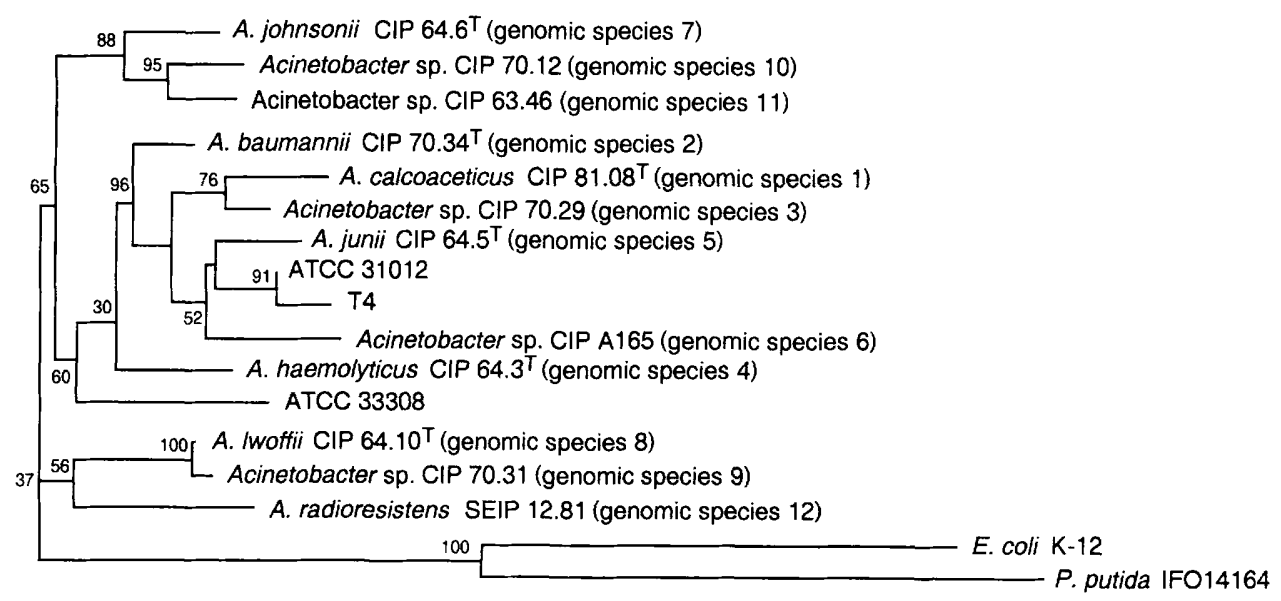

.10

FIG. 3. Phylogenetic tree for the strains of Acinetobacter based on the amino acid sequences of gyrB products by the neighbor-joining method. The numbers shown next to the nodes indicate percent bootstrap values of the 500 replicates. Distances were computed by using maximum-likelihood estimates based on the Dayhoff PAM matrix (10).

strain of Juni's transformation assay for the identification of Acinetobacter strains at the genus level (27), and this strain was not strongly linked to any genomic species.

Phylogenetic structure based on the amino acid sequences of GyrB. The phylogenetic tree based on the amino acid sequences of GyrB is shown in Fig. 3. The branching order of the GyrB-based tree was very similar to that based on the gyr $B$ nucleotide sequences; the only difference between these trees was the position of $A$. baumannii (genomic species 2).

Nucleotide substitution which provokes amino acid substitution is less frequent than synonymous substitution. The rate of amino acid substitution may be influenced by the percentage of amino acids essential for function, and each protein can be expected to have its own evolutionary speed. In the case of gyrB, the amino acid substitution rate was calculated to be one-third of the nucleotide substitution rate (Fig. 4). To examine the phylogeny of closely related bacteria, the analysis of nucleotide sequences may be superior to that of amino acid sequences, as higher numbers of substitutions are found in the former sequences. When the divergence of two compared nucleotide sequences is high and base substitutions can be expected to have occurred at most potential sites, the analysis of amino acid sequences may give a more accurate phylogenetic tree. In the case of the taxonomic position of $A$. baumannii, the nucleotide sequence analysis may provide better resolution, as the number of substituted amino acids between the sequences of $A$. baumannii and other related strains was small, being around 10.

Comparison with other phylogenetic analyses. The result of a phylogenetic analysis using gyrB nucleotide sequences was consistent with those using DNA-DNA hybridization and phenotype comparison. These classical analyses have demonstrated the clustering of genomic species 1,2 , and 3 and that of genomic species 8 and $9(5,45)$. The cluster analysis of 95 carbon source utilization profiles generated by the Biolog system (4) also suggested linkages between genomic species 4 and 6 , between genomic species 10 and 11 , and between genomic species 8 and 12 (2). All of these linkages were observed in the gyrB-based phylogenetic tree (Fig. 2).

On the other hand, the topology of the phylogenetic tree based on the 16S rRNA sequences was quite different from that based on the gyrB sequences $(34,50)$. In the $16 \mathrm{~S}$ rRNA sequence analysis done by Rainey et al., four genomic species $(1,4,7$, and 8$)$ and two genomic species (2 and 5) were grouped (34). Neither of these clusters was detected by DNA-DNA hybridization, by phenotypic characterization, or by our gyr $B$ sequence analysis. Thus, the $16 \mathrm{~S}$ rRNA gene sequence analysis may not be appropriate to deduce phylogenetic relationships among closely related bacteria. The aberrant structure of the 16S rRNA gene-based phylogenetic tree may have been due to statistical errors during the analysis of the small numbers of substitutions. Since a large part of the primary and secondary

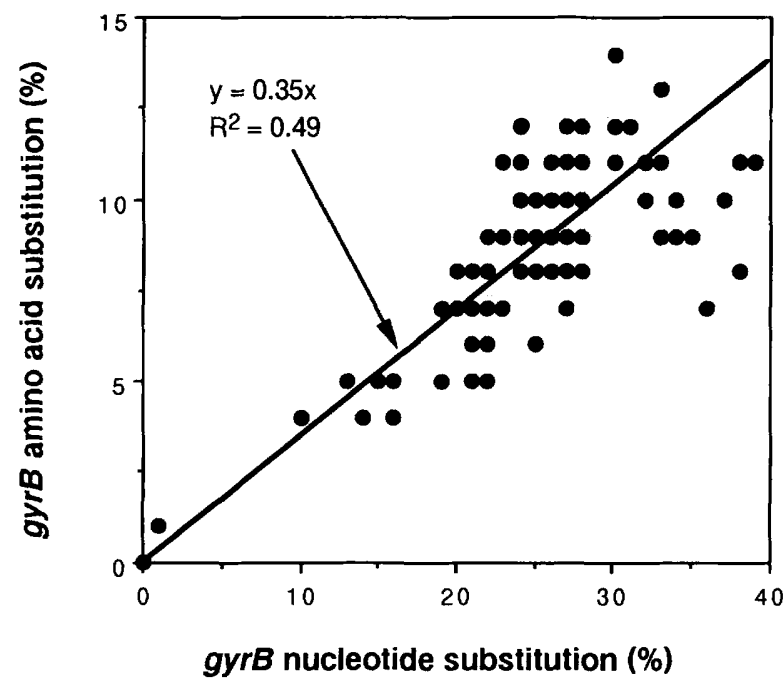

FIG. 4. Comparison of the nucleotide substitution frequencies of $g y r B$ and of the amino acid substitution frequencies of $g y r B$ products. Substitution frequencies between all the possible combinations of the Acinetobacter strains were calculated and plotted. The nucleotide substitution frequencies were corrected for multiple substitutions by using the Kimura and Ohta equation (30). $\mathbf{R}^{2}$ indicates the coefficient of correlation. 
structures of 16S rRNA is important for its functions, the evolution speed of $16 \mathrm{~S}$ rRNA is extremely low $(9,20)$.

Conclusions. As shown in this study, the gyrB sequence analysis is a rapid and effective method for identifying bacterial species and for examining phylogenetic relationships. Theoretically, any protein-coding sequence can be used for a phylogenetic analysis. However, many genes, especially those for catabolism, are known to spread horizontally among different bacterial species, and they cannot be used to trace the evolutionary record of host bacteria. Criteria for selecting appropriate taxonomic marker genes may be that (i) they are essential for housekeeping activities such as DNA replication, transcription, and translation; (ii) they are a single copy on each genome; and (iii) at least two regions are conserved for PCR amplification by using primers complementary to the conserved regions. We have conducted a search for such genes and conclude that $g y r B$ may be the best for such a purpose.

The genus Acinetobacter is a highly diverse taxonomic group (69.6 to $99.7 \%$ identity in the gyrB sequences), in comparison with the genetic proximity between Pseudomonas putida IFO $14164^{\mathrm{T}}\left(=\right.$ ATCC $\left.12633^{\mathrm{T}}\right)$ and Escherichia coli $\mathrm{K}-12(74.6 \%$ identity; Fig. 2 and Table 1). It will be necessary to clarify the taxonomic positions of the Acinetobacter genomic species with respect to other closely related genera.

\section{ACKNOWLEDGMENTS}

We are grateful to Shigeto Miyachi and Kasthuri Venkateswaran for encouragement and to Ikuko Hiramatsu and Hitoshi Ogawa for technical assistance. We also thank Philippe J. M. Bouvet for supplying the strains.

This work was supported by Industrial Science and Technology Frontier Program from New Energy and Industrial Technology Development Organization.

\section{REFERENCES}

1. Adriaens, P., and D. D. Focht. 1991. Cometabolism of 3,4-dichlorobenzoate by Acinetobacter sp. strain 4-CB1. Appl. Environ. Microbiol. 57:173-179.

2. Bernards, A. T., L. Dijkshoorn, J. Van der Toorn, B. R. Bochner, and C. Van Boven. 1995. Phenotypic characterization of Acinetobacter strains of 13 DNA-DNA hybridization groups by means of the Biolog system. J. Med. Microbiol. 42:113-119.

3. Bifulco, J. M., J. J. Shirey, and G. K. Bissonnette. 1989. Detection of Acinetobacter spp. in rural drinking water supplies. Appl. Environ. Microbiol. 55:2214-2219.

4. Bochner, B. R. 1989. Sleuthing out bacterial identities. Nature (London) 339:157-158.

5. Bouvet, P. J. M., and P. A. D. Grimont. 1986. Taxonomy of the genus Acinetobacter with the recognition of Acinetobacter baumannii sp. nov, Acinetobacter haemolyticus sp. nov., Acinetobacter johnsonii sp. nov., and Acinetobacter junii sp. nov. and amended descriptions of Acinetobacter calcoaceticus and Acinetobacter lwoffii. Int. J. Syst. Bacteriol. 36:228-240.

6. Bouvet, P. J. M., and P. A. D. Grimont. 1987. Identification and biotyping of clinical isolates of Acinetobacter. Ann. Inst. Pasteur Microbiol. 138:569-578.

7. Bouvet, P. J. M., and S. Jeanjean. 1989. Delineation of new proteolytic genomic species in the genus Acinetobacter. Res. Microbiol, 140:291-299.

8. Bouvet, P. J. M., S. Jeanjean, J. F. Vieu, and L. Dijkshoorn. 1990. Species, biotype, and bacteriophage type determinations compared with cell envelope protein profiles for typing Acinetobacter strains. J. Clin. Microbiol. 28:170176.

9. Dams, E., L. Hendriks, Y. Van der Peer, J.-M. Neefs, G. Smits, I. Vandenbempt, and R. De Wachter. 1988. Compilation of small ribosomal subunit RNA sequences. Nucleic Acids Res. 16:r87-r173.

10. Dayhoff, M. O., R. M. Schwartz, and B. C. Orcutt. 1978. A model of evolutionary change in proteins, p. 345-352. In M. O. Dayhoff (ed.), Atlas of protein sequence and structure, vol. 5, suppl. 3. National Biomedical Research Foundation, Washington, D.C.

11. Dijkshoorn, L., R. Van Dalen, A. Van Ooyen, D. Bijl, I. Tjernberg, M. F. Michel, and A. M. Horrevorts. 1993. Endemic Acinetobacter in intensive care units: epidemiology and clinical impact. J. Clin. Pathol. 46:533-536.

12. Felsenstein, J. 1981. Evolutionary trees from DNA sequences: a maximum likelihood approach. J. Mol. Evol. 17:368-376.

13. Felsenstein, J. 1989. PHYLIP-phylogeny inference package (version 3.2) Cladistics 5:164-166.
14. Fitch, W. M. 1971. Toward defining the course of evolution: minimum change for a specific tree topology. Syst. Zool. 20:406-416.

15. Fox, G. E., E. Stackebrandt, R. B. Hespell, J. Gibson, J. Maniloff, T. A. Dyer, R. S. Wolfe, W. E. Balch, R. S. Tanner, L. J. Magrum, L. B. Zablen, R. Blakemore, R. Gupta, L. Bonen, B. J. Lewis, D. A. Stahl, K. R. Luehrsen, K. N. Chen, and C. R. Woese. 1980. The phylogeny of prokaryotes. Science 209:457-463.

16. Fox, G. E., J. D. Wisotzkey, and P. J. Jurtshuk. 1992. How close is close: 16S rRNA sequence identity may not be sufficient to guarantee species identity. Int. J. Syst. Bacteriol. 42:166-170.

17. Gerner-Smidt, P. 1992. Ribotyping of the Acinetobacter calcoaceticus-Acinetobacter baumannii complex. J. Clin. Microbiol. 30:2680-2685.

18. Gerner-Smidt, P., and I. Tjernberg. 1992. Acinetobacter in Denmark. II. Molecular studies of the Acinetobacter calcoaceticus-Acinetobacter baumannii complex. APMIS 101:826-832.

19. Goldman, S., Y. Shabtai, C. Rubinovitz, E. Rosenberg, and D. L. Gutnick. 1982. Emulsan in Acinetobacter calcoaceticus RAG-1: distribution of cell-free and cell-associated cross-reacting material. Appl. Environ. Microbiol. 44: $165-170$.

20. Gutell, R. R., B. Weiser, C. R. Woese, and H. F. Noller. 1985. Comparative anatomy of 16-S-like ribosomal RNA. Prog. Nucleic Acid Res. Mol. Biol. 32:155-216.

21. Hansen, W., and E. Yourassowsky. 1991. Cellular fatty acid composition of Acinetobacter strains. Microbios 65:195-203.

22. Hartstein, A. I., V. H. Morthland, J. J. Rourke, J. Freeman, S. Garber, R. Sykes, and A. L. Rashad. 1990. Plasmid DNA fingerprinting of Acinetobacter calcoaceticus subspecies anitratus from intubated and mechanically ventilated patients. Infect. Control Hosp. Epidemiol. 11:531-538.

23. Higgins, D. G., A. J. Bleasby, and R. Fuchs. 1992. CLUSTAL V: improved software for multiple sequence alignment. Comput. Appl. Biosci. 8:189-191.

24. Hillis, D. M., and M. T. Dixon. 1991. Ribosomal DNA: molecular evolution and phylogenetic inference. $\mathrm{Q}$. Rev. Biol. 66:411-453.

25. Johnson, J. L. 1981. Genetic characterization, p. 450-472. In P. Gerhardt, R. G. E. Murray, R. N. Costilow, E. W. Nester, W. A. Wood, N. R. Krieg, and G. B. Philips (ed.), Manual of methods for general bacteriology. American Society for Microbiology, Washington, D.C.

26. Jolly-Guillou, M. L., E. Bergogne-Berezin, and J. F. Vieu. 1990. A study of the relationships between antibiotic resistance phenotypes, phage-typing and biotyping of 117 clinical isolates of Acinetobacter spp. J. Hosp. Infect. 16:4958.

27. Juni, E. 1972. Interspecies transformation of Acinetobacter: genetic evidence for a ubiquitous genus. J. Bacteriol. 112:917-931.

28. Kampfer, P., I. Tjernberg, and J. Ursing. 1993. Numerical classification and identification of Acinetobacter genomic species. J. Appl. Bacteriol. 75:259268.

29. Kimura, M. 1980. A simple method for estimating evolutionary rates of base substitutions through comparative studies of nucleotide sequences. J. Mol. Evol. 16:111-120.

30. Kimura, M., and T. Ohta. 1972. On the stochastic model for estimation of mutational distance between homologous proteins. J. Mol. Evol. 2:87-90.

31. Nishimura, Y., T. Ino, and H. lizuka. 1988. Acinetobacter radioresistens sp. nov. isolated from cotton and soil. Int. J. Syst. Bacteriol. 38:209-211.

32. Olsen, G. J., C. R. Woese, and R. Overbeek. 1994. The winds of (evolutionary) change: breathing new life into microbiology. J. Bacteriol. 176:1-6.

33. Picard, B., and P. Goullet. 1990. Epidemiological typing of Acinetobacter strains by esterase electrophoresis. FEMS Microbiol. Lett. 60:229-234.

34. Rainey, F. A., E. Lang, and E. Stackebrandt. 1994. The phylogenetic structure of the genus Acinetobacter. FEMS Microbiol. Lett. 124:349-353.

35. Regev, R., T. Dolfin, I. Zelig, S. Givoni, and B. Wolach. 1993. Acinetobacter septicemia: a threat to neonates? Special aspects in a neonatal intensive care unit. Infection 21:394-396.

36. Reisfeld, A., E. Rosenberg, and D. Gutnick. 1972. Microbial degradation of crude oil: factors affecting the dispersion in sea water by mixed and pure cultures. Appl. Microbiol. 24:363-368.

37. Saitou, N., and M. Nei. 1987. The neighbor-joining method: a new method for reconstructing phylogenetic trees. Mol. Biol. Evol. 4:406-425.

38. Sambrook, J., E. F. Fritsch, and T. Maniatis. 1989. Molecular cloning: a laboratory manual, 2nd ed. Cold Spring Harbor Laboratory, Cold Spring Harbor, N.Y.

39. Sawula, R. V., and I. P. Crawford. 1972. Mapping of the tryptophan genes of Acinetobacter calcoaceticus by transformation. J. Bacteriol. 112:797-805.

40. Schloesser, R. L., E. A. Laufkoetter, T. Lehners, and C. Mietens. 1990. An outbreak of Acinetobacter calcoaceticus infection in a neonatal care unit. Infection 18:230-233.

41. Seifert, H., A. Schulze, R. Baginski, and G. Pulverer. 1994. Plasmid DNA fingerprinting of Acinetobacter species other than Acinetobacter baumannii. J. Clin. Microbiol. 32:82-86.

42. Shotts, E. J., T. F. Albert, R. E. Wooley, and J. Brown. 1990. Microflora associated with the skin of the bowhead whale (Balaena mysticetus). J. Wildl. Dis. 26:351-359.

43. Sokal, R. R., and C. D. Michener. 1958. A statistical method for evaluating systematic relationships. Univ. Kans. Sci. Bull. 28:1409-1438. 
44. Stackebrandt, E., and B. Goebel. 1994. Taxonomic note; a place for DNADNA reassociation and $16 \mathrm{~S}$ rRNA sequence analysis in the present species definition in bacteriology. Int. J. Syst. Bacteriol. 44:846-849.

45. Tjernberg, I., and J. Ursing. 1989. Clinical strains of Acinetobacter classified by DNA-DNA hybridization. APMIS 97:595-605.

46. Towner, K. J., E. Bergogne-Bérézin, and C. A. Fewson. 1991. Acinetobacter: portrait of a genus. FEMS Symp. 57:1-24.

47. Walters, M., D. Milton, L. Larsson, and T. Ford. 1994. Airborne environ- mental endotoxin: a cross-validation of sampling and analysis techniques. Appl. Environ. Microbiol. 60:996-1005.

48. Woese, C. R. 1987. Bacterial evolution. Microbiol. Rev. 51:221-271.

49. Yamamoto, S., and S. Harayama. 1995. PCR amplification and direct sequencing of gyrB genes with universal primers and their application to the detection and taxonomic analysis of Pseudomonas putida strains. Appl. Environ. Microbiol. 61:1104-1109.

50. Yamamoto, S., and S. Harayama. Unpublished data. 